\title{
Lasallian Virtues: A Biblical Landscape
}

\author{
A. O. Oloo
}

\section{ABSTRACT}

This article is based on the Lasallian virtues while at the same time borrowing insights from five Biblical personalities namely Adam, Noah, Abraham, Joseph, son of Jacob, and Moses respectively. Therefore, the purpose of the study was to examine these personalities in relation to the twelve Lasallian virtues as well as their attitudinal disposition in responding to their call of faith. Specific objectives are in tandem with these virtues, that is, piety, prudence, patience, self-control, silence, gentleness, gravity, humility, wisdom, zeal, vigilance, and generosity. A descriptive research design and qualitative research methods were adopted. The aforementioned five Biblical personalities were selected using purposive sampling technique. Pertinent data were collected from the Holy Bible through desk research. Inferential citations and selected Biblical texts were the point of focus. Content analysis-exegesis was employed in qualitative data analysis. The analysis was guided by the theory of underdogs, misfit and the art of battling giants. It was revealed that the studied personalities faced their figurative Goliaths. Adam faced the serpent, Noah faced the unbelieving people before the deluge, while Abraham, Joseph, and Moses had to confront the Egyptian Pharaoh. Obedience was the Lasallian virtue that featured in all of these personalities from Adam to Moses. Other dominant virtues included piety, wisdom, prudence, patience, humility, zeal, self-control, and generosity. The study recommended that we embrace the Lasallian virtues. Irrespective of the Goliaths that we may face in our lives, it is recommended that we put our trust in God and have faith in Him similarly to how the studied Biblical personalities approached challenges during their times.

Keywords: Abraham, Adam, Biblical landscape, Biblical personalities, Joseph, Lasallian virtues, Moses, Noah

Published Online: February 22, 2022

ISSN: 2736-5514

DOI: $10.24018 /$ ejtheology.2022.2.1.56

\section{A. O. Oloo}

Lasalle School, Homa Bay, Kenya

(e-mail: antone.oloofsc@ gmail.com)

\section{INTRODUCTION}

For many years in the past, there have been talks about virtues in different religions based on their beliefs and faith. Ancient scholars such as Aristotle, Socrates and Plato all mentioned in their works something to do with virtues of which some have been adopted by early Roman Writers. Distinguished Christian writers like Saint Ambrose, Augustine, and Thomas Aquinas added some theological virtues such as faith, hope and charity. To the early Greeks, they saw virtues more in relation to the human behavior and reasoning while the Christians attributed them to God's revelation through faith in Christ. Traditional Christian understanding of virtues has been defined as conformity of life and conduct with the principles of morality. The twelve Lasallian Virtues were organized and written by Br. Agathon (1777 - 1795) who was by then the Fifth Superior General of the Brothers of the Christian Schools. Psychologically they can be grouped into four categories based on the teacher's life as an educator. To start with is the personal relationship with God, as always, the creator comes first in anything we do as believers. That is Piety which shows the devout or strong believe and devotion to one's spiritual practices.

The second group of virtues helps personal development of a person and more relevant to the work of a teacher. They are prudence, patience, reserve, silence and gentleness. The third group of virtues helps in the relationship between a teacher and students. They are gravity, wisdom and humility. In the fourth group, they help in actual teaching in a classroom situation as they are very practical to how a person expresses self towards others. They are Zeal, vigilance and generosity.

According to Br. Agathon, these virtues are responsible in developing attitudes necessary for the mission of an educator. Three main attitudes have been sighted in his writings and the first one is to make a person to be able to discern interiorly towards personal enrichment and freedom. Personal enrichment and inner freedom is very essential in building the confidence of a teacher in order to perform in class. The second attitude is self-mastery which results in a balanced personality and ability to discern. Teaching profession leads one to meet people of different personalities hence a balanced person should be able to handle them in different situations. Finally, the third attitude is commitment of the teacher to his work of education. 


\section{PURPOSE}

The purpose of the study was to examine the twelve Bible personalities in relation to the twelve virtues as well as their attitudinal disposition in responding to their call of faith. Concerning the aforesaid virtues, not all of them were applicable to each personality; rather, the ones that matched the personality and agreed with the episode in which they were involved in were put into perspective.

\section{RESEARCH QUESTIONS}

The following research questions will guide the attitudinal application to the Bible actors. This is in conformity to the actors' response to God's call to participate in the salvation history. What was their attitudinal position in terms of;

i. Interior disposition and freedom of choice in response to their situation?

ii. Balanced personality and mastery or understanding of their role in their mission?

iii. Their commitment?

\section{Specific ObJectives}

Specifically, the following are the objectives that guided this study. They fall under five groups of virtues as demonstrated here below.

\section{A. First Group of Virtue}

\section{1) Piety}

Piety is the only virtue under this category. In respect of this virtue, personal relationship with God is the main focus based on the life of the person. The objective was to examine how the way of life is analyzed to establish the kind of devotion that existed as at that time. How the person's experience of God inspired the others as at the time, and how providence through seeing things in the eyes of faith manifested itself in their life.

\section{B. Second Group of Virtue}

These group of virtues are very helpful in the development of a person. They depict themselves from the Bible personalities and the changing life episodes that they were involved in their journey of faith. They include prudence, patience, reserve or self-control, silence, and gentleness.

\section{1) Prudence}

The objective was to analyze how the Biblical personalities employed their intelligence to make judgement of their situation or situations, how they were involved in handling situations during their encounter with God and challenges at the time, the relevance of their actions towards the decisions they made, as well as how their intelligence applied to the episodes that followed after their encounter with God.

\section{2) Patience}

Temperament is one of the most difficult thing to control especially during challenges. The objective was to examine how they were able to control their reactions to situations especially during persecutions and how such contributed to their mission. Another objective was to analyze their reflective patterns and factors that led them to overcome trials and temptations.

\section{3) Reserve/Self-Control}

The objective was to examine the self-control virtue of Biblical personalities. Knowing very well whom they were dealing with and the government of the time these personalities must have had high self-control in the manner in which they expressed themselves. For instance, in their environment, not many kings at the time were very open regarding their religion. Therefore, they needed a lot of moderation on how they could pass on their ideas in relation to the salvation mission they were involved in.

\section{4) Silence}

Freedom of expression is very important in order to pass information for those involved in evangelization. At the same time sieving what to say is very important and this virtue is very necessary in this area. The pertinent objective was to assess how the selected Biblical personalities managed to use the 'silence' virtue and control their communication so as to make it very effective as per what they intended to pass across to their society at the time. 
European Journal of Theology and Philosophy

www.ej-theology.org

\section{5) Gentleness}

The act of balancing kindness and firmness, courtesy and authority. This requires the use of other virtues too like prudence and wisdom. Apart from Jesus who portrayed perfectly his gentleness, the objective was to analyze how other men of God applied gentleness from three main perspectives, that is, the gentleness of heart, manner and conduct.

\section{Third Group of Virtues}

These virtues are necessary for one to develop relationship with other individuals. They include gravity, humility, and wisdom.

\section{1) Gravity (Seriousness)}

We cannot live alone in this world. Thus it is necessary to make friendships and other relations at the work place. However, maintaining friendship at the same time balancing familiarity, seriousness, intimacy and kindness in a professional climate can be a challenge. In that case, we have to distinguish between fear and respect in our activities. Therefore, in respect of this virtue, the objective of the study was to evaluate how the Bible personalities managed their salvation mission.

\section{2) Humility}

Being human is not an option for us; rather, it is part of us right from creation. We have to live with all our human qualities in whatever we do in our daily life. The focus here is to look at the humanistic aspect in respect of Matthew 18:3 "Unless you change and become like little children, you will not enter the kingdom of God". Pertinently, the objective of the study was to examine how the selected Biblical personalities were able to avoid qualities that repelled others exemplified by envy, jealousy, and superiority among others and still be able to attract people of God to their mission.

\section{3) Wisdom}

The virtue of prudence helps us in taking the right action as per the scenario we are in. This virtue of wisdom purifies the action done by prudence and further gives the reason behind the action. At times, using prudence may give us the right action but wisdom limits us to wait for the right time to take the necessary actions. This is how these virtues can interchange in their roles in our lives. The objective of the study was to establish how the virtue of wisdom was evident in the Bible stories.

\section{Fourth Group of Virtues}

This group is very essential in the application of daily work involvement of a person. These virtues demonstrate how a person executes normal daily routine in a mission.

1) Zeal

Accepting our mission and assignments or jobs willingly and lovingly gives us the energy to serve with certain kind of confidence and freedom. When working without stress, we tend to perform better than when we feel oppressed or forced. Zeal gives us the energy to do the job wholeheartedly. According to the Bible stories, the objective was to examine how the 'Zeal' virtue was depicted among the key players being looked at in this study.

\section{2) Vigilance}

Awareness is very important in our daily life and in our environment. Today a lot is happening in the world ranging from Covid-19 pandemic to environmental issues like global warming. Awareness can be looked at in three different ways in the following manner:

$\checkmark$ To look - directing our eyes towards a certain direction or towards something

$\checkmark$ To watch - giving attention to what we are looking at

$\checkmark \quad$ To see - Identifying the details of what we are paying attention to

This virtue of vigilance gives us these three dimensions of awareness. In tandem, the objective of this study was to examine the bible stories and how they can be applied in today's daily life.

\section{3) Generosity}

It is in giving that we get more. This virtue requires the use of many other virtues as it comes from the heart. The objective of the study was to analyze how generosity was depicted from the Bible stories of salvation history. Reference can be made from the ministry of Jesus in Galilee starting at the wedding in Cana and many other episodes that were related to generosity. 


\section{METHODOLOGY}

The methodology describes the theory or procedure of carrying out research. Of interest are the research design and methods, population, sampling procedure, data collection procedure as well as methods of analyzing the collected data.

\section{A. Research Design and Methods}

This study adopted a descriptive research design alongside qualitative research methods. Descriptive research is associated with the description of a phenomenon (for instance, Lasallian virtues demonstrated by Biblical personalities) and its characteristics (Nassaji, 2015). The choice of the descriptive research design was thus informed by the fact the study sought to describe the characteristics of the selected Biblical personalities Qualitative methods are non-statistical (Saunders, Lewis, \& Thornhill, 2007). It is asserted that qualitative research and descriptive research are, at times, employed interchangeably though they may differ in respect of their extent of control, their goal, and how the collected data are analyzed. The desirability of the qualitative research approach is founded on the fact that it is more holistic since, oftentimes, it involves a rich collection of pertinent data from an array of sources with the objective of gaining a deeper comprehension or understanding of individual participants including their attitudes and perspectives of the phenomenon being investigated (Nassaji, 2015). Qualitative approach was embraced in this study with the view of having an in-depth understanding of the selected Biblical personalities particularly from Lasallian perspective.

\section{B. Target and Accessible Population}

The target population constituted personalities presented in the Holy Bible. This population is defined as an aggregate of individuals sharing similar or related characteristics in respect of a given phenomenon. It is also described as the group of participants (relative to a given study) sharing particular attributes of interest and relevance (Creswell, 2003). The accessible population, which is a subset of target population (Asiamah, Mensah, \& Oteng-Abayie, 2017), comprised Biblical personalities with special characteristics especially those that demonstrated Lasallian values or virtues.

\section{Sample Size and Sampling Technique}

A total of 12 Biblical personalities spanning both the Old and New Testaments were selected using purposive sampling technique. These personalities included Adam, Noah, Abraham, Joseph son of Jacob, Moses, King David, King Solomon, Prophet Jeremiah, Prophet Daniel, Joseph husband to Mary, Mary mother of Jesus Christ and Apostle Paul. Purposive, otherwise referred to as judgmental, sampling refers to a technique whereby particular events, persons or settings are deliberately selected with the view of obtaining from them crucial information that cannot be accessed from other available choices (Taherdoost, 2016). The study used Biblical exegesis in analyzing the callings of the aforesaid Biblical personalities. Each of them acts like a bend of a river as it flows down-stream to a large water body. Contextually, in our today's world, they would act like toll stations at every point of the road or where there is a major junction.

Adam opens the creation story, while Noah ends one era of generation and begins another era after the deluge. Abraham opens the beginning of faith in Yahweh and a very strong tradition of the monotheistic religions of the world. Joseph son of Jacob, on the other hand, marks the first saviour of the Israelites in Egypt thus resembling the savior (Jesus Christ) to come in years later. Moses leads Israelites from slavery in Egypt while King David unites all the 12 tribes of Israel and builds the strongest Jewish Kingdom hitherto. King Solomon becomes the last King of the United Israel. Prophet Jeremiah and Daniel became strong messengers of God in Captivity. Joseph and Mary became the human parents of Jesus the Christ while Apostle Paul spread the Gospel to the rest of the world and founded the first Christian communities.

\section{Data Collection Procedure}

Desk research was used to collect data in respect of the aforementioned Biblical personalities. It is indicated that desk research is an approach that involves a critical evaluation and analysis of secondary data as well as existing literature (Zhou \& Nunes, 2016). This approach embodies two distinct characteristics: Exclusively depends on published secondary data, and all desk research processes are carried out in-house (Jackson, 1994). Pertinently, the data in respect of this study were obtained from the Holy Bible. Data were collected through inferential citations, which included selective biblical texts in line with the values under study.

\section{E. Data Analysis Methods}

The collected data were analyzed using qualitative methods. The qualitative data were analyzed using content analysis-exegesis. The analysis of the data with regard to this study was premised on the theory of underdogs, misfit and the art of battling giants (Malcolm, 2015). The choice of this method was founded on the assertion that data can be analyzed qualitatively using a suitable theory or theories. This is similar to 
a past study which examined data type and data analysis in qualitative and descriptive research (Nassaji, 2015). According to this theory, Goliath expected a physical fight against his opponent David and he was sure he would win due to his physical advantage. Goliath under-rated the view in which David perceived him as a 'dog' by approaching him armed with a stick and a sling. Little did Goliath know how lethal the sling was, since, ironically, Davis used it to kill him. David was able to manipulate the whole scenario by changing tactics contrary to the expectation of many including his main opponent, Goliath.

In tandem with this theory, Malcom suggested that every one of us always faces a figurative 'Goliath' kind of challenge or problem. Borrowing from David's case, we can always approach the 'Goliaths' in our lives by changing our tactics to the ones that are applicable, thus leading to less casualty on our side. Fundamentally, we have to be as innovative as we can in order to face 'Goliaths' in our daily lives. In this study, most of the chosen Biblical personalities had some form of 'Goliaths' in their lives who they had to deal with during their call to participate in the salvation history. Some of the difficult situations and people the aforesaid personalities had to face in their mission which is in line with tenets of this theory are illustrated in Table 1.

TABLE I: BiblicAl PERSONALITIES AND THEIR RESPECTIVE GOLIATHS

\begin{tabular}{cc}
\hline \hline Biblical Personalities & Figurative Goliaths (Situations or Persons Representing Goliath) \\
\hline Adam & The Snake \\
Noah & Hostility of the unbelieving society just before the deluge \\
Abraham & Egyptian Pharaoh \\
Joseph son of Jacob & Egyptian Pharaoh \\
\hline \hline
\end{tabular}

\section{RESUlTS AND DISCUSSION}

The results of the data analysis provided information that formed the basis for discussion, conclusion, and interpretation of the findings and recommendations of the study. The results as demonstrated in this section indicated that there existed a relationship between values and calling into a vocation. The results of the qualitative analysis of the selected Biblical personalities are presented in respect of how these personalities faced their 'Goliaths'. The results are further discussed from Lasallian perspective. The personalities are presented in a chronological order starting with Adam and ending with Apostle Paul.

\section{A. Adam}

The book of Genesis is cognizant about the creation narratives in the Bible. According to the African Bible, Genesis is divided into four main parts. These include Genesis 1:1-11:26 which talks about the foundation of life and history of mankind, Genesis 11:27-25 which talks about the origin of the people of God and the other two parts Genesis 25:19-36:43 and Genesis 37:1-50:26 covers the Patriarchs Isaac and Jacob as well as the story of Joseph and his brothers respectfully.

In respect of this study, the interest is in the first two parts of Genesis where Adam features mostly as the first human to open up the salvation history as he is mentioned in the Gospel of Luke 3:23-38, which illustrates the genealogy of Jesus Christ being connected all the way to Adam son of God. Among the four Gospels only Luke connects Adam to Jesus in the genealogy contrary to Mathew who starts his genealogy from Abraham in Matthew. 1:2. Matthew could have been influenced by his Jewish background which strongly believed in Abraham as their father of faith.

According to Genesis 1:27-28 God created man in his own image and empowers mankind to procreate and fill the world; creating them both male and female. Looking at the second account of creation from Genesis 2:4-7, man was created out of clay and God blew breath into him. Woman was created later out of the ribs of man (Adam) (Gen. 2:21). Therefore, by the virtue of Adam being given power of procreation and being the image of God, he automatically assumed all the good virtue of obedience since he received instructions from the creator directly.

Both Jesus and Adam share one very unique and important virtue of obedience as they were referred in Paul's first letter to the Corinthians, 1 st Cor. 15:45 "And so it is written, the first man Adam was made a living soul; the last Adam was made a quickening spirit." Jesus in Luke 22:42 "Father, if you are willing, take this cup from me; yet not my will, but yours be done." Jesus obeyed the will of His Father even on the precipice of death in order to save the world. Obedience is one of the greatest virtues that builds relationship with one another especially in situations where one is superior to the other or others.

Gravity falls under the third group of virtues which plays a crucial role in person-to-person relationships. In Gen. 1:22-24 gravity is demonstrated by Adam in the manner in which he accepted his partner (Eve) in life. He used the phrases 'bone of my bones and flesh of my flesh' then refers to his partner as "woman". This was a very powerful and intimate way of accepting a person in one's life thus creating a very powerful bond in relationship. The Gospel of John. 6:53 thus states, "So Jesus said again, Itell you the truth, unless 
you eat the flesh of the Son of Man and drink His blood, you cannot have eternal life within you". These scripture demonstrates how Jesus stressed the powerful and strong relationship He expected from His followers whereby they had to embrace His way of life totally in both deeds and faith. The first and second Adam were giving the best example of obedience to emulate with the creator in the human's journey of faith. It can be learnt from them how seriously it is need to keep the people's relationship with God by relating with those we are entrusted to be with in our apostolates and daily living.

From Adam's story humans are created in the image of God. People are not God but being in His image empowers men to do things in His likeness. Therefore, every person is in the image of God, thus is God's likeness. What does this mean to people's life as believers and how are they supposed to live with these people around them. Adam presents vital reflections of accepting whoever is given to the people to live with. This is akin to the way he accepted Eve without any questions or prejudices or conditions, but he only saw the good works of the Lord in Eve. Adam teaches the mankind to see good in others and accept them the way they are since they are God's creation. Adam was the first environmentalist from the way he appreciated the Garden of Eden. The consequences of destroying the environment are disastrous from what happened to him and Eve when they were chased away from the Garden of Eden. The continuous distraction of the garden of Eden (today it is, figuratively, the Earth) is what is slowly creating unbearable conditions for life to exist. This could range from destruction of ozone layer by excessive emission of poisonous gases, changing rainfall patterns, diseases like corona virus disease (Covid-19), chemical poisoning from nuclear products and malignant cancer in the present-day beliefs and morals. The only difference of present day's situation vis-à-vis Adam's time is that God is not going to chase us from the Earth; rather, the humans are the ones destroying themselves by destroying their environment.

Contextually, De La Salle in his meditations reminds the mankind that they are co-workers with God. 'To work in the vineyard means to be partners with God in helping in his work of spreading the Gospel of His Son" (MTR 193.1). De La Salle emphasizes that people are God's messengers in their different ministries, hence, it is our duty to protect God's creation in people's work. In this way the human can see themselves as the current Adam who is the minister of God in his Garden which is where people are assigned to work and live.

\section{B. Noah}

The African Bible commentary translates Gen. 3:17 "to the man he said, 'because you listened to your wife and ate from the tree of which I had forbidden you to eat, cursed be the ground because of you" I toil shall you ear its yield all the days of your life.' As a curse to the ground which is coming from the sin of Man in the Garden of Aden. Therefore, the word 'Noah' which in Hebrew means 'relief' comes in handy as someone who brings hope to the mankind by obeying the word of God in order to bring salvation. His agricultural skills lessened the curse of the soil (Gen. 3:17). Noah was born and lived at a time when the world was already full of evil people and God regretted that he had created man in the very first place (Gen. 6:5). This was the situation that led God to make a decision to wipe out the entire humanity from the surface of the earth apart from Noah and his household since he found favour in God.

The virtue of obedience was manifested in the way Noah received instructions on how to build the Ark (Gen. 6:14). He followed all the instructions given to him by God until the day when the floods hit the earth. According to Gen. 6:21, he was given instructions to provide all the foodstuff he will need with his family and animals in the ark during the deluge. For him to fulfill this, he needed a lot of wisdom and prudence in identifying all kinds of foodstuff that were going to sustain them for over 100 days. The two virtues were also reflected in the actual building of the ark. This was due to due to the fact the ark required proper designs in order to make it float on water as well as accommodate all what God had told him to put on board.

The ark remained afloat for a duration of a hundred and fifty days (Gen. 8:3) before the water levels subsidized enough to for the ark to settle on the ground thus allowing Noah and his team to disembark. This required a lot of patience which seemed to have been well understood by Noah. Patience with God is a great virtue as God's time is always the best for us to implement our views, ideas and actions in accordance with his plans. As the ark was floating, they were completely in God's mercy as they could not control or steer it to any direction as they could have potentially willed. Noah believed in God and had great faith such that he believed in whatever direction God guided the ark. This kind of strong faith brought out the virtue of piety in Noah depicting his devotion to, and relationship with God. Piety was also seen as he built an altar to offer sacrifice to God in Gen. 8:20 and verses 21 where God made a covenant with Noah which showed how strong their relationship was.

In the Gospel of Mark 4:35-41, Jesus calmed the storms as the disciples were afraid that their boat would capsize due to the great storm. Jesus reminded his disciples to have great faith in God as He is always in control of situations. The disciples lacked piety amid the storm, hence, it demonstrated their weak faith as compared to Noah who remained calm in the ark during the deluge. 
European Journal of Theology and Philosophy

www.ej-theology.org

\section{Abraham}

The three major monotheistic religions of the world which are Christianity, Judaism and Islam regard Abraham as a great man of faith in their respective holy books. Gen. 12:1-4 talks about the call of Abraham and his sending to a land that he had not known hitherto. Abraham's acceptance to God's call automatically brings out the virtue of obedience, and his willingness to go to unknown place reflects the virtue of piety. He had such great faith in God that he never doubted God's command thus leaving his kinsmen and departed to a foreign land.

Gen. 12:12 "When the Egyptians see you, they will say, 'she is his wife' they will kill me, but let you live." This verse shows the great wisdom Abraham had after assessing the situation of the Egyptians and how they lived their lives. In verse 13, he advised his wife to introduce herself as his sister in order to spare his life for the sake of both of them. As God's chosen person, Abraham had to survive in order to fulfill his mission as a key person in the salvation history and safeguard the lineage of which a savior was to come from in the latter years.

It was very prudent of Abraham to escape severe famine in Negeb and emigrate to the land of Egypt. He knew that, with all the livestock he had, the great famine was not going to spare them. On the other hand, after the episode of the Pharaoh with his wife, he ended up benefiting with more animals when he was sent away after the plague hit the Pharaoh's household (Gen. 12:17).

Abraham's wisdom continued to manifest itself as he settled the differences between his herdsmen and those of Lot, his brother's son (Gen. 13:8-13). According to the African Bible, the conflict between uncle and son portrayed the nobility of Abraham in addressing issues. He was more interested in a harmonious and peaceful co-existence as opposed to material wealth. Even though as an elder he had the right to choose which side of land to settle, he still humbled himself and gave his nephew the first opportunity to make his choice. This event expressed his humility as a virtue as well as generosity by giving his nephew the best part of the land willingly and with a lot of parental love. Continuing from verses 14 of the same chapter, God rewarded him even more from his generosity thus showing the mysterious ways of God's blessings upon those who are obedient to him. The African Bible commentary pointed out that what seemed a disadvantage would turn out to be a blessing.

In Gen. 14:12, Lot was captured and taken to captivity during an invasion by foreign kings. News reached Abraham about what had transpired. His response was very swift and elaborate as demonstrated by how he planned to rescue him. The zeal in him built great confidence such that he organized his men and worked out a revenge attack to rescue his kinsmen. He made his attack at night, which brought out the vigilance in him by being aware of the weakness of the enemy. Upon their return, the king of Sodom offered him all the gifts he had captured but declined, and instead gave him most of the loot. This brought out his generosity (Gen.14:21-24). Abraham's generous tendency extends to strangers as reflected in Genesis 18 when he had an encounter with three men of God who paid him a visit. He treated them with utmost respect and concern at first without knowing they were God's messengers, a revelation that came out later in Gen. 18:14.

In Genesis 17:17, God promised Abraham a child but at the age of a hundred years and the wife ninety years, Abraham found it very impossible for her wife to bear a child. This notion was very difficult for them to understand particularly given that Sarah had stopped having her menstrual periods (Gen 18:11). However, God's ways are not man's ways thus Abraham's piety and patience with God earned him great favours. He believed that God's time was the right time for everything that He guided him to do. These unpredictable ways of God's revelation to man continued throughout in many other episodes captured in the Bible that were to follow. For instance, crossing of the Red Sea (Exodus 14), among others which demanded great manifestation of faith and patience with God. Therefore, Abraham's experience underscores that, what seemed completely impossible to man was very possible with God.

In the episode of God testing Abraham's faith by asking him to sacrifice his son, Isaac, he showed the greatest degree of his obedience to God (Gen. 22:11). Abraham knew very well that Isaac was to be the heir of his wealth and the generation to come but he never argued with God. He believed in the complete providence of God. He never had any plans of slaughtering a ram or another animal, but completely left the whole matter to God's providence to guide him. This episode showed how sometimes God's mission could appear to be very suicidal and dangerous then, ironically, all turns out to be victorious and beneficial. From the analysis of the Biblical personalities and their encounter with God, obedience to God seems to be one of the greatest virtues that keeps on repeating in most of God's calling events.

Contextually, a time comes in life when one feels like the only option remaining is to give up the one which they are dearly attached to or love the most. Abraham's teaching is that it is God who gives as He did it to him in his old age and He can take it away. Faith in God surpasses all the wealth one could wish to have in this world. Faith and prayer cannot be seen, but their effect is greater and visible than any 
European Journal of Theology and Philosophy

www.ej-theology.org

mountain on earth. This is very much evident from the covenant God made with Abraham in which he was promised to have descendants as many as the stars in heaven.

\section{Joseph the Son of Jacob}

Sometimes in life events happen in a peculiar way that a person completely loses hope. One can only see death as the option remaining but then, all of a sudden, things start changing in even more estranged ways that are very difficult to comprehend. Eventually, hope comes back but in a completely different scenario that cannot be connected to the first event that put you into problems. This is exactly what happened to Joseph and his brothers.

The story of Joseph reveals how human decisions and evil intentions can be overturned by God's love and mercy to His chosen people. It can also be seen as how God's grace is present in the mankind as demonstrated even in the worst human scenarios that can be thought of on earth. Rejection is a very painful experience especially if it comes from the loved ones of whom it is least expected. The rejection of Joseph by his brothers was a preparation of what was to happen in the Gospel to Jesus who later on became the saviour of the world. Joseph too became the savior of Israelites in Egypt during the famine.

Obedience comes out clearly as the first virtue Joseph possessed (Gen. 37:13) when he willingly and lovingly took instructions from his father to go and take food to his brothers who were in the fields taking care of their father's livestock. Joseph never questioned or doubted his father's instructions even after knowing very well the reaction of his brothers towards him after he had previously explained his dreams to them (Gen. 37:7-8).

Joseph had a great personal experience with God out of his virtue of piety. He completely trusted in Him as demonstrated in different episode since the time he was thrown into the well by his brothers. God is seen protecting him out of this relationship or Joseph having favour with Him. This can be seen from Gen. 37:21 where his brother, Rueben, saved his life by suggesting a different option of throwing him into a dry well. In Gen. 39:14 when he was falsely accused of attempting to sleep with his master's wife, he was thrown into jail, but ironically developed a good relationship with the jail master (Gen. 39:23). Joseph affirmed his piety when in Gen. 40:8 he told Pharaoh's courtiers (the chief baker and the cup bearer) that interpretation of dreams comes from God so they told him their dreams so that he could help them interpret. This act was repeated in Gen. 41:16 when Joseph told Pharaoh that it was not him who interpreted dreams but God himself did it through him. This happened just before he started to interpret to Pharaoh his dreams.

Sometimes in life, we may have doubts about how our investment in others may eventually benefit us or our organizations. We may wonder about the character and motives of the people we help. However, St. Paul in his letter to the Galatians (Gal. 6:10) wrote "Whenever we have an opportunity, let us work for the good of all." Just like what Joseph did to the two Pharaoh's servants who were also sent to jail with him, one of them eventually helped him out and played a big role in connecting him to Pharaoh. It was his good act of interpreting the dream of the cup bearer that saved him, since the cupbearer was able to remember who helped him while he was in jail. Therefore, Joseph was generous to share with others his gift from God of interpreting dreams. He extended his generosity to King Pharaoh and eventually God rewarded him by putting him in charge of Egypt (Gen. 41:37).

In Gen. 41:33 Joseph advised Pharaoh to seek out a wise person and discerning man to be put in charge of the land of Egypt in order to manage the good and the hard times that were to come. Pharaoh, instead, turned to Joseph to be the one to do it after consulting with his officials (Gen. 41:39). This episode of Joseph translating Pharaoh's dreams and eventually being appointed to a higher position portrays him as a man of great wisdom.

In Luke 3:23, Jesus started his ministry when he was aged thirty years. At the beginning of this chapter, Joseph was mentioned as the one who was resembling the saviour to come in the later years from the lineage of Abraham. Joseph's characteristics of being rejected, then favoured by God later on to be the saviour of Israelites resembles those of Jesus who went through same rejection from his own people. Another similarity is depicted in Gen. 41:46 when Joseph was thirty years old. He became a governor in charge of Egypt, a position which gave him the vantage position to save the Israelites when the right time came during the famine.

Joseph's sons Manasseh and Ephraim reminded him of his bitter past and success in a foreign land. The name Manasseh meant "God has made me forget entirely the sufferings I endured at the hands of my family" (Gen. 41:51). On the other hand, the name Ephraim meant "God has made me fruitful in the land of my affliction" (Gen. 41:52). Remembering these experiences could have made Joseph very sad and emotional because he loved his family very much and could not revenge against them. It is these feelings and memories that after recognizing his brothers (Gen. 42:24), Joseph wept for the pain was unbearable. However, he never let them discover his grief due to him possessing the virtue of self-control (reserve), thus handling the scene in a very mature way. Similar grief can be found in the Gospel of John 11 when 
Jesus performed his seventh miracle during his ministry. Jesus loved Lazarus and his two sisters very much (Jn. 11:5). He felt so much pity for them and shared their pain when he arrived and found them mourning Lazarus (the friend he loved) that he wept (Jn. 11:35).

The Gospel of John 1 reminds us of Jesus incarnation to mankind. Therefore, Jesus knew very well that he was going to raise Lazarus and so he needed not to weep. But in this case, he was standing in between the living and the dead with full knowledge of what was to happen next. The African Bible commentates that Lazarus became the key symbol of the power and meaning of Christ as the resurrection and the life. Jesus brings back the gift of life after four days, an act that he was to go through in three days towards the end of his ministry on earth before His ascent to heaven forty days later. The weeping could have very many translations with other Bible commentators, but this chapter only focuses more on connection to Joseph in Egypt as the saviour of the Israelites during his time. The saving act of Joseph to his brothers came after he wept and that opened up his virtue of generosity to them. In Gen. 42:25, he gave orders for their sacks to be filled with food and their money put back in them without them knowing. They would later discover their money had been put back on their return journey home.

The virtue of prudence is clearly demonstrated by Joseph when he gave his brothers conditions to fulfill as exemplified by his request for them to bring back his younger brother in order for him to release the elder one, and how he tricked them by putting his silver goblet in the back of the younger one's sack. He did all these tests out of love as he was buying time patiently in order to find the right time to reveal himself to them. Something unique happened due to the great love he had for his brothers and that is when he, for the second and third time, wept because of his brothers (Gen. 43:30, Gen. 45:14 and Gen. 46:29). Therefore, the total number of times Joseph wept for the love of his own people of Israel and the joy of reuniting with them were four. Jesus too wept three times during his ministry. Apart from the raising of Lazarus from the dead, Jesus wept for Jerusalem (Lk. 19:4) and on the cross on his fourth statement while he was in pain fulfilling his salvation mission. Prophet Isaiah. 53:12 thus states, "Jesus of Nazareth fulfills the Messianic prophecy for the suffering servant of the Lord".

Throwing into darkness of Joseph by his brothers manifested his life floating to no apparent direction like Noah's ark reflected in the story of Noah. It is in such scenarios in life whereby we are faced by issues ranging from family, work, relationships, etcetera. The only thing that God wants from us is faith and trust in Him. If we could only leave everything in His hands, then by His will our ark will float to safety just like Noah's ark did. It happened to Joseph in a foreign land where he knew nobody, but in faith he floated to safety and ended up saving others who had dumped him to be swallowed by the floods of the worldly life.

\section{E. Moses}

Moses was a very important figure in the Jewish history since he was seen as their saviour from the land of Egypt. Great persecution of the Israelites was announced by Pharaoh who came to power and had no knowledge of the Israelites and Joseph (Ex. 1:8). Egyptian midwives too were commanded to kill any new born Jewish baby boy and leave the girls to survive (Ex. 1:15). Similar massacre was experienced in the Gospel when Herod ordered the massacre of children (baby boys) below the age of two (Mt. 2:16-17). Both Herod and Pharaoh were seen to be afraid of other powers other than themselves, thus being self-centered persons/leaders. Moses and Jesus were both seen as saviours by the Jewish and Christians respectively and shared the same circumstances during their birth whereby each of them had to be hidden from the enemy in different circumstances befitting their time of birth. These incidences are respectively found in Ex. 2:14 and Mt. 1:13.

Vigilance is the first virtue that appears in the story of Moses. Having been raised by his mother in the Pharaoh's court (Ex. 2:7-8), he might have been informed about his roots by his own mother in the palace. Therefore, he grew up knowing very well that he was a Jew. This awareness led to the incident captured in Exodus 2:12 where he killed an Egyptian who was oppressing a Jew and hid him in the Sand. He later fled to Midian in the fear that Pharaoh might have heard the news and his penalty could have been devastating. He wanted justice for his fellow Israelites and this quest for justice remained in him even when he defended the daughters of a Priest of Midian named Jethro by the well (Gen. 2:17).

During the call of Moses at Mount Horeb, his vigilance which created curiosity in wanting to know his surroundings and being alert all the time led him to find out more about the burning bush. He had a character of wanting to know what was around him and what was going on. His curiosity enabled him to be always alert. However, at some point this worked against him by doubting what he was being told by God to do. He would question what he did not understand, and would want an assurance before he could proceed to his next move. It is stated in Genesis 3:11 that, "But Moses said to God, "who am I that I should go to Pharaoh and lead the Israelites out of Egypt?" He was questioning God at this stage, something very unique in him as compared to his predecessors like Noah, Abraham and Joseph who believed in God and had great piety. The questioning of God continued further in Genesis 3:13 where God gave him an answer and an assurance to confront the Israelites who he was leading. Before Moses could leave for his mission, 
God gave him a great sign that showed the kind of work he was about to do and this required high intelligence from Moses' side in order for him to understand (Ex. 4:2-5). This was exemplified by his staff changing to a serpent.

In Ex. 4:2-5 God instructed Moses to throw the staff in his hand on the ground, then it turned into a serpent. Moses moved back in fear of the serpent. This fear of serpent can be traced back to Gen. 3:1 where the serpent is presented as the root of evil and most cunning amongst all animals. The image of serpent here was well understood by Moses as very dangerous which in this case could represent the dangerous mission that he was about to undertake of facing Pharaoh in Egypt. Knowing very well how dangerous this mission was, he jumped backwards from the serpent (the mission). Ironically, God commanded him to touch the serpent by the tail. This was another extremely dangerous act according to Moses with the assumption that he had hitherto lived in the desert for a long period of 40 years and he had vast knowledge of poisonous desert snakes. So why was God asking him to make such a suicidal move knowing very well the consequences (touching a snake by the tail would prompt it to spring back and attack)? This perturbed Moses as he hesitated to touch it by the tail as instructed, a move that made the serpent to turn back to the staff. The incident helped to build Moses piety and trust in the Lord, because if he did not trust in the Lord he would not have touched the snake by the tail. God used known things to Moses like staff and snake which is common knowledge for any shepherd in the desert at that time in order to make him understand the divine mission of salvation ahead of him.

With this trust now built in him, the incident prepared him for the tough task ahead (meeting Pharaoh) (who could be interpreted as the dangerous serpent) and facing all that would happen with the same trust he had of touching the snake by the tail. Moses was fully aware from his experience when he lived in Pharaoh's court that messing with Pharaoh was as good as courting death because Pharaoh was known to put people to death by his orders. The foregoing is what prompted Moses to run away after killing the Egyptian (Ex. 2:12).

Moses recognized his weakness as a stammerer and he accepted it despite being alive to the fact that it would hinder his work as a God's messenger. Accepting one's own weakness and accepting to be assisted is great humility for any leader. This is a great virtue that reminds us of our human weakness and make us realize that we cannot be islands of ourselves. God's mission requires collaborative work with others who are in the same mission and understanding for it to be successful. This was why Moses requested his brother Aron to assist him in his difficult task of dealing with Pharaoh (Ex. 4:10 and 7:1).

From Ex. 7:14 to Ex. 11, the plagues are explained one by one and how they took place. During these plagues, Moses was very obedient to the Lord and followed all the instructions. Moses and his brother, Aron, cooperated fully with the Lord God keeping all the instruction given per every plague as they followed each other. During the fourth plague, where a swarm of insects invaded all of Egypt except Goshen where the Israelites were living, Pharaoh summoned Moses and Aron to give them his mind. He instructed them to go and offer sacrifice to their God but Moses objected since Israelites sacrifices were an abomination to the Egyptians. This argument brought out Moses' prudence and wisdom at the same time as he responded swiftly and intelligently keeping in mind the situation on the ground and the effect it may cause to the Israelites should he had proceeded and adhered to Pharaoh's request (Ex. 8:22). Moses knew very well by now that the Egyptians were very angry with them due to the plagues and any slight act of blasphemy to their belief or religion would cause serious reaction towards the Israelites like stoning them to death.

During the 10-plague period, Moses exhibited two other very important virtues according to how he was handling the situation. He and Aron kept on going back and forth to the Pharaoh's palace as they juggled between orders from Yahweh and the arrogance of Pharaoh. They took Yahweh's order with a lot of zeal and executed all the instructions as given during the plagues. They also exercised a lot of patience with Pharaoh as this took so many days from the first plague to the time of Passover feast before they were allowed to leave Egypt.

In Ex.14:11-13, the Israelites saw Pharaoh coming towards them with his army and fear gripped them. They made all sorts of complaints and accusations to Moses and forgot that they were on their journey to freedom. Moses, on the other hand, out of his piety and strong relationship with God, was able to control himself and handle the complaints calmly. By this time, he had matured a lot in his relationship with Yahweh such that he was never worried any more but believed that Yahweh was in control of their journey. The grumbling and complaints of the Israelites did not stop. They continued complaining even when they were in the desert (Ex. 16:3) but Moses, possessing the virtue of self-control, was able to handle all these situations that were arising from time to time. The story of Exodus remains one of the greatest and memorable ones both in the Jewish tradition as well as the Christian salvation history. It has been used and translated to mean different scenarios in our journey of faith during retreats as we reflect about our own journey of faith in our today's world. 


\section{CONCLUSIONS AND RECOMMENDATIONS}

\section{A. Conclusions}

There are several Lasallian core virtues. However, in respect of this study the virtues of interest include prudence, patience, being reserved or having self-control, silence, gentleness, gravity, humility, wisdom, zeal for service, vigilance, and generosity. The aforesaid virtues have been examined from the Biblical perspective. The biblical personalities examined in the study are Adam, Noah, Abraham, Joseph son of Jacob, and Moses respectively. Each of these personalities faced a figurative 'Goliath' in their lifetime. The approach with regard to how they confronted their respective 'Goliaths', manifested in key challenges they faced, demonstrated their virtues which have are applicable in today's life in form of Lasallian virtues. Overcoming of these challenges is concluded to present the Biblical personalities as saviours of sorts. Adam's main challenge was the serpent which lied to them through Eve and eventually found them to fall out of favour with God, the Creator. Adam demonstrated the virtues of obedience and gravity. The Adam's case leads to the conclusion that people are God's messengers in their different ministries and capacities to protect God's creation in people's work. Noah's 'Goliath' was the incessant hostility of the unbelieving people prior to the deluge who had sinned so much that God found it right to eliminate them from the service of the earth. Noah demonstrated several virtues, that is, obedience, wisdom, prudence, patience, and piety. Akin to Jesus saving His disciples from the threat of the stormy waters, the study concludes that Noah saved the mankind from the threat of extinction since he and his household are the only persons that survived the then deluge.

Abraham, the first patriarch, Joseph the son of Jacob, and Moses faced similar 'Goliaths' in their lifetime: The Egyptian Pharaoh. It is inferred that, Abraham's virtue of wisdom to confront Pharaoh, for instance, by lying to him that his wife, Sarah, was his sister ostensibly to save both their lives. Other eminent virtues expressed by Abraham include piety, obedience, prudence, humility, generosity, zeal, vigilance, and patience. In tandem with Lasallian virtues, Abraham's teachings underline why we should have faith in God in our daily undertakings. Joseph in his confrontation of challenges and relationship with God reflected several virtues similar to Lasallian ones. They are obedience, piety, wisdom, self-control, generosity, and prudence. Joseph's approach to challenges relative to his trust and faith in God was likened to that embraced by Noah. The salvation aspect is demonstrated by Joseph's intervention during the famine when he was a highly-respected leader in Egypt. The virtues expressed by Moses included vigilance, wisdom, humility, obedience, prudence, zeal, self-control, and patience. The salvation concept was manifested when Moses led the Israelites out of Egypt.

\section{B. Recommedations}

In emulating the teachings of the five Biblical personalities, it is recommended that we embrace the Lasallian virtues. Following the case of Adam, it is recommended that seek to protect the God's creation and not to fall into temptations that can lead us to fall out of favour with God. From the deluge experience, we can learn from Noah's relationship with God and handling of the then situation, to be obedient, prudent, and wise in our choices and the decisions we make. We should demonstrate piety and patience in our relationship with God for He will always stop the floods and calm the storms in our lives. In line with Abraham's teachings, the study recommends we embrace the virtues of wisdom, humility, and prudence. We should also be vigilante and generous in our relations with our kith and kin. From the experiences of Joseph the son of Jacob, the study recommends that exhibit obedience in dealing with our parents and the elderly. The virtue of piety in our relation with God is also emphasized. It is also important to share with others our God-given gifts similar to how Joseph shared his gift of interpreting dreams with the Pharaoh's servants. We should not avenge those who wrong us, rather, we should be prudently generous towards them as Joseph demonstrated in his relationship with his brothers when they met in Egypt in time of famine. Akin to the Abraham's case, the teachings from Moses recommend us to embrace the virtues of piety and patience in our faith and trust in God. Regardless of the Goliaths in our lives, God will always intervene and his providence will ever be timely. Therefore, it is advisable for us to stop worrying and leave everything to God for His guidance.

\section{REFERENCES}

Asiamah, N., Mensah, H. K., \& Oteng-Abayie, E. F. (2017). General, target, and accessible population: Demystifying the concepts for effective sampling. The Qualitative Report, 22(6), 1607-1622.

Creswell, J. W. (2003). Research design: Qualitative, quantitative and mixed methods approaches (2nd ed.). London, UK: Sage Publications.

Jackson, P. (1994). Desk research (market research). Tucson, AZ: Kogan Page.

Malcolm, G. (2015). David and Goliath: Underdogs, misfits, and the art of battling giants. New York, NY: Amazon Publishing. 
European Journal of Theology and Philosophy www.ej-theology.org

Nassaji, H. (2015). Qualitative and descriptive research: Data type versus data analysis. Language Teaching Research, 19(2), 129132. doi:10.1177/1362168815572747

Saunders, M., Lewis, P., \& Thornhill, A. (2007). Research methods for business students (4th ed.). Harlow, England.

Taherdoost, H. (2016). Sampling methods in research methodology; how to choose a sampling technique for research. International Journal of Academic Research in Management (IJARM), 5(2), 18-27.

Zhou, L., \& Nunes, M. B. (2016). Formulating a framework for desktop research in Chinese information systems. In J. T. Martins, \& A. Molnar, Handbook of research on innovations in information retrieval, analysis, and management (pp. 307-325). Hershey, PA: IGA Global. doi:10.4018/978-1-4666-8833-9.ch011

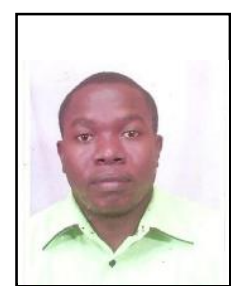

\section{Br. Oloo Onyango Antone, FSC}

Holds Master's degree in educational administration and planning awarded by the Catholic University of Eastern Africa, Nairobi City, Kenya. He also possesses a Bachelor of Education in religious studies from the Saint May's University of Minnesota, Nairobi Campus, Kenya; Diploma in religious studies and Diploma in Education, both awarded by Tangaza College based in Nairobi City, Kenya. In tandem, the author has authored three articles in peer reviewed academic journals. Oloo possesses working experience in school administration spanning more than 10 years. Presently, he is the founding Director of Lasalle School based in Homa Bay, Kenya. He previously founded Lasalle Catholic School, Nairobi (2016 - 2020) after being the Principal of Mwangaza College in Nakuru Kenya for the period 2013 to 2015. Between 2010 and 2012, he was the Principal St Paul's Secondary School, Catholic Diocese of Marsabit, Kenya while between 2007 and 2009, the author was the Dean of Studies, Rongai Boys in the Catholic Diocese of Nakuru, Kenya. 